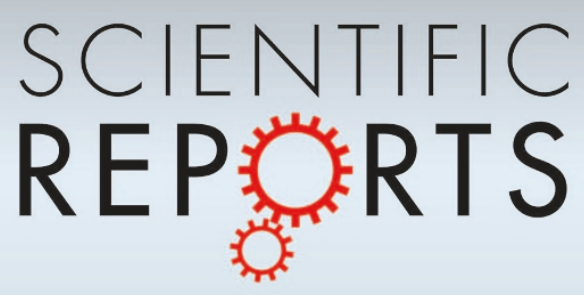

OPEN

SUBJECT AREAS:

ECOSYSTEM ECOLOGY

RESTORATION ECOLOGY

FOREST ECOLOGY

Received

31 March 2014

Accepted

11 August 2014

Published

2 September 2014

Correspondence and requests for materials should be addressed to S.F. (sfu@scbg.ac.cn)

\section{Response of soil respiration and} ecosystem carbon budget to vegetation removal in Eucalyptus plantations with contrasting ages

Jianping Wu' ${ }^{1}$, Zhanfeng Liv ${ }^{2}$, Guomin Huang ${ }^{3}$, Dima Chen ${ }^{4}$, Weixin Zhang ${ }^{2}$, Yuanhu Shao ${ }^{2}$, Songze Wan ${ }^{2}$ \& Shenglei Fu ${ }^{2}$

${ }^{1}$ Institute of Ecology and Environmental Science, Nanchang Institute of Technology, Nanchang 330099, China, ${ }^{2}$ Key Laboratory of Vegetation Restoration and Management of Degraded Ecosystems, South China Botanical Garden, Chinese Academy of Sciences, Guangzhou 510650, China, ${ }^{3}$ Hawkesbury Institute for the Environment, University of Western Sydney, Richmond, NSW 2753, Australia, ${ }^{4}$ State Key Laboratory of Vegetation and Environmental Change, Institute of Botany, Chinese Academy of Sciences, Beijing 100093, China.

Reforested plantations have substantial effects on terrestrial carbon cycling due to their large coverage area. Although understory plants are important components of reforested plantations, their effects on ecosystem carbon dynamics remain unclear. This study was designed to investigate the effects of vegetation removal/ understory removal and tree girdling on soil respiration and ecosystem carbon dynamics in Eucalyptus plantations of South China with contrasting ages ( 2 and 24 years old). We conducted a field manipulation experiment from 2008 to 2009 . Understory removal reduced soil respiration in both plantations, whereas tree girdling decreased soil respiration only in the 2-year-old plantations. The net ecosystem production was approximately three times greater in the 2-year-old plantations $\left(13.4 \mathrm{t} \mathrm{C} \mathrm{ha}^{-1} \mathrm{yr}^{-1}\right)$ than in the 24-year-old plantations $\left(4.2 \mathrm{t} \mathrm{C} \mathrm{h}^{-1} \mathrm{yr}^{-1}\right)$. The biomass increase of understory plants was $12.6 \mathrm{t} \mathrm{ha}^{-1} \mathrm{yr}^{-1}$ in the 2-year-old plantations and $2.9 \mathrm{t} \mathrm{ha}^{-1} \mathrm{yr}^{-1}$ in the 24-year-old plantations, accounting for 33.9\% and $14.1 \%$ of the net primary production, respectively. Our findings confirm the ecological importance of understory plants in subtropical plantations based on the 2 years of data. These results also indicate that Eucalyptus plantations in China may be an important carbon sink due to the large plantation area.

iven the rapid increase in atmospheric $\mathrm{CO}_{2}$ concentrations, estimation of the terrestrial carbon cycle in various biomes is urgently needed ${ }^{1,2}$. Because large amounts of carbon are retained in living plant and soil organic matter, the emission of these carbons into the atmosphere as $\mathrm{CO}_{2}$ would have a profound effect on the global climate ${ }^{3}$. Recent interest in understanding how $\mathrm{CO}_{2}$ emission from soils (or soil respiration) influences the global carbon cycle and its potential feedback on climate change has resulted in a growing number of studies ${ }^{4-6}$. Because soil respiration is the second largest carbon flux between terrestrial ecosystems and the atmosphere, releasing 10 times as much $\mathrm{CO}_{2}$ to the atmosphere as the combustion of fossil fuels, it is imperative to investigate the impacts of human disturbance on ecosystem $\mathrm{C}$ dynamics, including soil respiration ${ }^{7,8}$.

Forests cover approximately 4.1 billion hectares of the Earth's land surface and have been estimated to account for $80 \%$ of all aboveground carbon and approximately $40 \%$ of all belowground terrestrial carbon ${ }^{1}$, which suggests the importance of forests in mitigating additional atmospheric $\mathrm{CO}_{2}$ emission ${ }^{9}$. In China, the total forest area is approximately 195 million hectares, and more than one-third of these forests are plantations ${ }^{10}$. Reforested plantations can sequester large amounts of $\mathrm{CO}_{2}$ and offset the negative effect of fossil carbon emission ${ }^{11,12}$. When assessing ecosystems as carbon sinks or sources, a central concept is net ecosystem production (NEP), which is defined as the net annual carbon accumulation ${ }^{13,14}$. Although numerous studies have shown that NEP is affected by temperature, moisture, and stand age ${ }^{15,16}$, few studies have addressed how forest NEP is affected by different plant components, such as trees vs. understory plants.

Previous studies have indicated that understory vegetation, which is influenced by both resource quantity and resource heterogeneity ${ }^{17}$, greatly affects the properties and processes in forest ecosystems ${ }^{18,19}$. However, previous studies examining carbon cycling in forest ecosystems usually focused on the dominant overstory plant species 
and failed to identify the role of understory plants ${ }^{18,20}$. Furthermore, information on the effect of understory plants on ecosystem carbon dynamics and storage, which is essential for predicting regional and global carbon cycling, remains unclear, particularly in systems with abundant understory plants.

Eucalyptus has been widely planted for reforestation in South China. In 2010, the total area of Eucalyptus plantations in South China was approximately 3.68 million ha ${ }^{21}$. Although Eucalyptus plantations grow rapidly and accumulate a large biomass, they contain many understory plants because of their open canopy ${ }^{22}$. As part of forest management, understory vegetation is usually removed from the forest floor to prevent fire and to promote the growth and regeneration of tree seedlings ${ }^{23}$. Little is known about how the removal of understory plants affects the carbon dynamics and storage in the ecosystem.

In this study, a manipulation experiment that included tree girdling and understory removal was used to examine how these treatments affected ecosystem carbon dynamics in two Eucalyptus plantations of different ages ( 2 and 24 years old). We hypothesized that (1) tree girdling and understory removal would decrease soil respiration by reducing the belowground $\mathrm{C}$ input and consequently affect ecosystem carbon storage; (2) the amount of carbon accumulation in the Eucalyptus plantations with contrasting ages would be influenced by understory plants because of their rapid growth at young ages and slow growth at mature ages.

\section{Results}

Soil temperature and soil moisture. The soil temperature and soil moisture were higher in the wet season (June to September) than in the dry season (October to March) in both types of plantations (Figure S1 and S2). Understory removal increased soil temperature by $1.04^{\circ} \mathrm{C}$ in 2009 and by $0.73^{\circ} \mathrm{C}$ across 2008 and $2009(P=0.003 ; P$ $=0.02$ ) in the 2 -year-old plantations (Table 1 ). The mean values of soil temperature and soil moisture did not vary significantly between 2008 and 2009 (Table 1, Figure S1 and S2).

Soil respiration. Repeated measures (RM) ANOVA indicated that soil respiration in plantations varied with sampling time $(P<0.05)$, with higher rates in the wet season than in the dry season (Table 1, Figure S1 and S2); however, there was no interaction among sampling time, understory removal, and girdling $(P>0.05)$. The effect of plantation age on soil respiration was not significant $(P>$ $0.05)$. In the 24 -year-old plantations, understory removal reduced soil respiration by $45 \%$ in $2009(P=0.001)$ and by $39 \%$ across 2008 and $2009(P=0.01)$. In the 2 -year-old plantations, understory removal reduced soil respiration by $19 \%$ in $2009(P=0.04)$ and by $16 \%$ across both 2008 and $2009(P=0.07)$. Based on RM ANOVA, girdling did not affect soil respiration in the 24-year-old plantations but did affect soil respiration in the 2-year-old plantations (Table 1 , Figure S1 and S2). In the 2-year-old plantations, girdling decreased soil respiration by $27 \%$ in $2008(P=0.02)$ and by $20 \%$ across 2008 and $2009(P=0.04)$.

Cumulative soil respiration. The cumulative soil respiration from March 2008 to March 2009 was highest in the control subplots (856 $\pm 116 \mathrm{C} \mathrm{m}^{-2} \mathrm{yr}^{-1}$ in the 2-year-old plantations and $670 \pm 68 \mathrm{~g} \mathrm{C}$ $\mathrm{m}^{-2} \mathrm{yr}^{-1}$ in the 24-year-old plantations) (Figure 1). The cumulative soil respiration in the 2 -year-old plantations was lowest in the subplots with understory removal plus girdling $\left(380 \pm 86 \mathrm{C} \mathrm{m}^{-2}\right.$ $\left.\mathrm{yr}^{-1}\right)$. The cumulative soil respiration in the 24-year-old plantations was lowest in the understory removal subplots $(455 \pm$ $57 \mathrm{~g} \mathrm{C} \mathrm{m}^{-2} \mathrm{yr}^{-1}$ ) (Figure 1). RM ANOVA showed that understory removal plus girdling in the 2 -year-old plantations and understory removal in the 24-year-old plantations significantly reduced the cumulative soil respiration compared with control plots $(P=0.02)$.

Fine root biomass. For both plantations, the fine root biomass was significantly reduced by girdling and by understory removal plus girdling (Figure 2). The fine root biomass was lowest in understory removal plus girdling plots, with values of 10.2 and $2.3 \mathrm{~g} \mathrm{~m}^{-2}$ in the young and mature plantations, respectively. Understory removal did not significantly affect the fine root biomass in the 2-year-old plantations but significantly decreased the fine root biomass in the 24-year-old plantations $(P=0.018$; Figure 2$)$.

Ecosystem carbon storage. From 2008 to 2009, increases in the diameter at breast height $(\mathrm{DBH})$, coarse root biomass, and understory biomass were greater for the 2-year-old plantations than for the 24-year-old plantations (Table 2). The net primary production (NPP) was greater for the 2-year-old plantations $\left(1717.4 \pm 123.11 \mathrm{~g} \mathrm{C} \mathrm{m}^{-2} \mathrm{yr}^{-1}\right)$ than for the 24-year-old plantations $\left(924.24 \pm 62.48 \mathrm{~g} \mathrm{C} \mathrm{m}^{-2} \mathrm{yr}^{-1}\right)$. The increase in understory plant biomass contributed $33.9 \% \pm 0.08$ to the NPP in the 2 -year-old plantations and $14.1 \% \pm 0.02$ to the NPP in the 24year-old plantations. The NEP values were consistent with the NPP values and were $1337.30 \pm 54.89 \mathrm{~g} \mathrm{C} \mathrm{m}^{-2} \mathrm{yr}^{-1}$ in the 2-year-old

Table 1 | Pvalues for repeated measures ANOVAs concerning the effects of sampling time (T), understory removal (UR), girdling (G), and their interactions on soil respiration, soil temperature, and soil moisture content in 2008, 2009, and across 2008 and 2009 (designated as "Both") in the 2-year-old and 24-year-old plantations

\begin{tabular}{|c|c|c|c|c|c|c|c|c|c|}
\hline Independent variable & \multicolumn{3}{|c|}{ Soil respiration } & \multicolumn{3}{|c|}{ Soil temperature } & \multicolumn{3}{|c|}{ Soil moisture content } \\
\hline \multicolumn{10}{|l|}{ 2-year-old plantations } \\
\hline$T \times U R$ & 0.81 & 0.14 & 0.60 & 0.009 & 0.001 & $<0.01$ & 0.92 & 0.1 & 0.18 \\
\hline$T \times G$ & 0.19 & 0.45 & 0.09 & 0.96 & 1 & 1 & 0.67 & 0.69 & 0.78 \\
\hline $\mathrm{T} \times \mathrm{UR} \times \mathrm{G}$ & 0.99 & 0.50 & 0.99 & 0.99 & 0.99 & 1 & 0.85 & 0.23 & 0.40 \\
\hline$U R \times G$ & 0.64 & 0.49 & 0.56 & 0.60 & 0.46 & 0.48 & 0.59 & 0.25 & 0.47 \\
\hline \multicolumn{10}{|l|}{ 24-year-old plantations } \\
\hline $\mathrm{T}$ & $<0.01$ & $<0.01$ & $<0.01$ & $<0.01$ & $<0.01$ & $<0.01$ & $<0.01$ & $<0.01$ & $<0.01$ \\
\hline$T \times U R$ & 0.01 & $<0.01$ & $<0.01$ & 0.002 & $<0.01$ & $<0.01$ & 0.09 & 0.82 & 0.41 \\
\hline$T \times G$ & 0.30 & 0.19 & 0.37 & 0.89 & 0.98 & 0.99 & 0.90 & 0.55 & 0.62 \\
\hline$T \times U R \times G$ & 0.17 & 0.52 & 0.43 & 0.97 & 0.93 & 0.99 & 0.96 & 0.77 & 0.91 \\
\hline
\end{tabular}




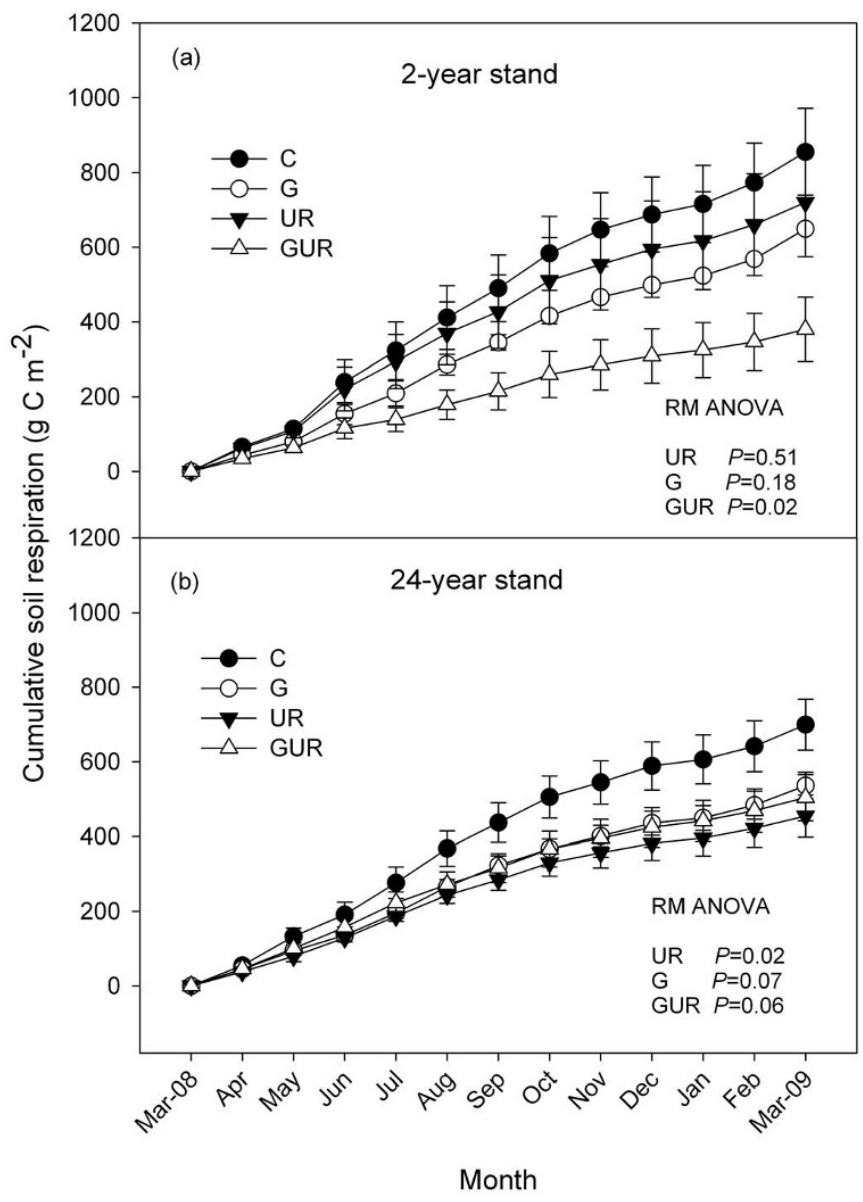

Figure 1 Cumulative soil respiration from March 2008 to March 2009 in the 2-year-old and 24-year-old plantations. Values shown are the mean \pm $1 \mathrm{SE} ; \mathrm{n}=3$. C, control; G, girdling; UR, understory removal; GUR, girdling plus understory removal. RM ANOVA $P$ values for the effects of G, UR, and GUR are indicated.

plantations and $420.15 \pm 120.75 \mathrm{~g} \mathrm{C} \mathrm{m}^{-2} \mathrm{yr}^{-1}$ in the 24-year-old plantations (Table 2). The plant biomass was greater in the 24-yearold plantations than in the 2 -year-old plantations $(P<0.01)$, but soil organic carbon and floor litter carbon did not differ between the young and old plantations (Figure 3 ). The total carbon storage also did not differ between the 2-year-old plantations and the 24-year-old plantations $(P=0.16$, Figure $3 \mathrm{~d})$, with values of $21.2 \pm 0.98$ and 24.4 $\pm 1.51 \mathrm{~kg} \mathrm{C} \mathrm{m}^{-2} \mathrm{yr}^{-1}$, respectively. Compared with other dominant forest types in China, the NPP and NEP of Eucalyptus forests were significantly higher than the other forest types and the average values for China's forest ecosystems (Table 3).

\section{Discussion}

Responses of soil respiration to tree girdling and understory removal. In the first year after tree girdling, soil respiration was decreased by $27 \%$ in the 2 -year-old plantations and by $22 \%$ in the 24 -year-old plantations. Decreases in respiration in the first year after girdling were greater in the current study than in previous studies in Eucalyptus plantations, in which respiration was reduced by only $14 \%^{29,30}$. The girdling of trees in boreal forests, however, caused even greater reductions in soil respiration; that is, tree girdling reduced respiration by $56 \%$ in the first year and $65 \%$ in the second year ${ }^{31,32}$. The different responses to girdling in Eucalyptus plantations vs. boreal forests can be attributed to the resprouting trait of Eucalyptus, which allows roots to live and continue to respire for more than 1 year after girdling. Our

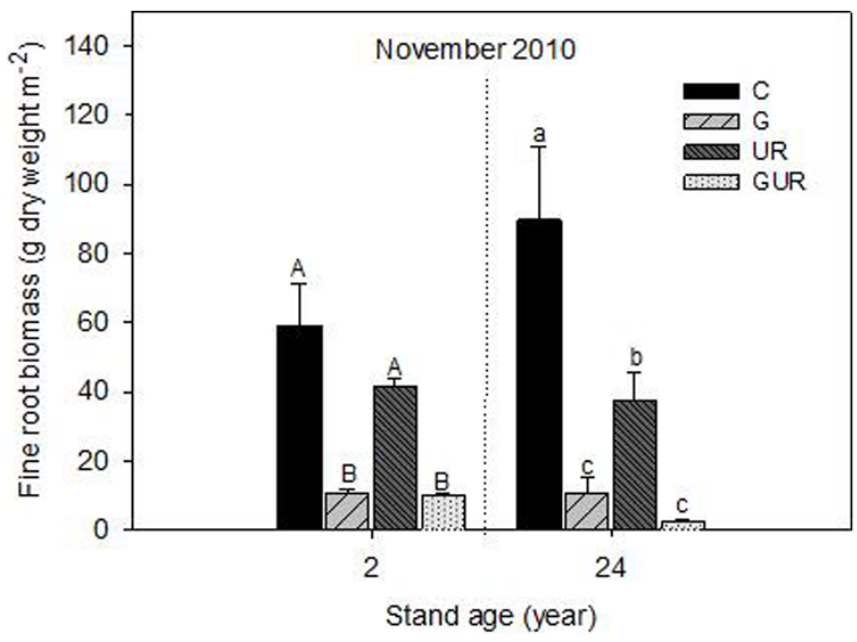

Figure $2 \mid$ Fine root biomass in the 2-year-old and 24-year-old plantations in November 2010. Values shown are the mean $\pm 1 \mathrm{SE} ; \mathrm{n}=3$. C, control; G, girdling; UR, understory removal; GUR, girdling plus understory removal. Within each plantation, values with different letters are significantly different $(P<0.05)$.

previous study showed that that $51 \%$ and $62 \%$ of the fine roots remained alive 1 year after girdling in the 2-year-old and 24-yearold plantations, respectively ${ }^{22}$; significant reductions in fine root biomass were not detected until 32 months after girdling. The dead roots also represent a new carbon input to soil and are important substrates supporting the heterotrophic respiration of soil microorganisms ${ }^{33}$.

Understory removal in the first year reduced soil respiration by $14 \%$ and $34 \%$ compared to the control in the 2 -year-old plantations and the 24-year-old plantations, respectively, suggesting that understory plant roots made substantial contributions to soil respiration ${ }^{19}$. In our previous study, understory plant removal in a plantation of mixed native tree species decreased annual soil respiration by only $6 \% 34$. We hypothesize that the effect of understory removal on soil respiration depended on species composition, plantation age, and stand structure ${ }^{35}$. For example, soil respiration was $4.2 \%$ higher in an oak forest with understory than without understory, whereas soil respiration was $22.6 \%$ higher in a scot pine forest with understory than without understory ${ }^{36}$.

Research has suggested that understory removal should increase soil water content due to decreased transpiration and that soil temperature should increase due to increased light penetration ${ }^{5}$. In our experiment, however, understory removal and tree girdling did not affect soil water content. This might be explained by a possible tradeoff between water use by trees and understory plants; a previous study reported that introduced Eucalyptus can consume more water than native species ${ }^{37}$. The soil temperature increased only during the second year of our study and only after understory removal in the 24year-old plantations. Because the treatments only marginally affected soil temperature and moisture, we inferred that soil temperature and soil moisture were not major factors affecting soil respiration in the present study. Our results indicated that nutrient availability partially explained the dynamics of soil respiration because the soil $\mathrm{NO}_{3}{ }^{-}-\mathrm{N}$ significantly increased after understory removal (Figure S4). We postulated that understory removal eliminated the nutrient translocation from soil to understory plants, consequently reducing the total soil respiration ${ }^{22}$.

The contribution of understory plants to ecosystem carbon storage. Understory species such as Dicranopteris often form a dense mat under the open canopy in tropical regions ${ }^{38}$. In both plantations in our study, however, the canopies are open, and 
Table 2 | Net primary production (NPP), net ecosystem production (NEP), and their components in a 2-year-old and 24-year-old Eucalyptus plantation from 2008 to 2009. Values are presented as the mean (SE); $n=3$. Within each row, values with different letters indicate significant differences between the two plantations for the same treatments $(P<0.05)$. Notes: $D B H$, diameter at breast height; $\Delta B_{\text {ab }}$ change in aboveground biomass; $\Delta B_{c}$, change in coarse root biomass; $\Delta B_{u}$, change in understory plant biomass; Rh, heterotrophic respiration; C, control; $G$, girdling; UR, understory removal; GUR, girdling plus understory removal

\begin{tabular}{|c|}
\hline Variable \\
\hline 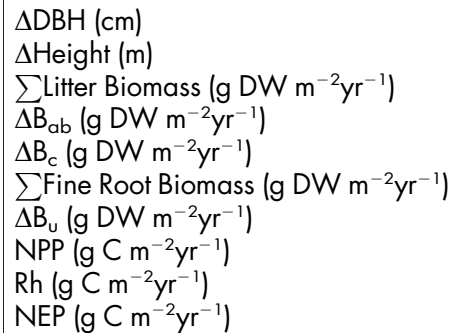 \\
\hline
\end{tabular}

2-year-old plantations
$2.35(0.10) a$
$2.33(0.52) a$
$431.1(84.6) a$
$1471.8(296.8) a$
$352.9(43.72) a$
$241.9(51.4) a$
$1260.4(444.2) a$
$1717.4(123.11) a$
$380.08(86.27) a$
$1337.30(54.89) a$

24-year-old plantations

understory plants receive abundant solar energy and grow rapidly. A recent study also showed that light heterogeneity directly influences the understory plant community ${ }^{39}$. Our results confirm that increases in plant biomass would be underestimated if understory plants are ignored ${ }^{40}$. The biomass of understory plants accounted for $20 \%$ and $31 \%$ of the total plant biomass in the young and mature plantations, respectively. These values would clearly be lower in a natural forest with a closed canopy ${ }^{41}$. For example, understory biomass was less than $3 \%$ of the total forest biomass in a natural tropical forest $\mathrm{t}^{42}$. However, in subtropical China, the understory layer could account for $10-19.9 \%$ of the total forest biomass and should not be ignored when assessing total carbon pools in the forest ecosystems of subtropical China ${ }^{43,44}$.

Our results indicate that understory plants in both Eucalyptus plantations accounted for more than $10 \%$ of the total NPP, which further indicates that understory plants are important components of these ecosystems. Meanwhile, the understory NPP was greater in the 2-year-old plantations than in the 24-year-old plantations, although the biomass of the understory plants was three times larger in the 24-year-old plantations than in the 2-year-old plantations. The potential reasons for the lower NPP in the mature plantations include the following: (1) understory plants grow more slowly as the Eucalyptus canopy develops ${ }^{45}$; (2) the competition by native understory plants would be stronger in the 2-year-old plantations than in the 24-year-old plantations ${ }^{22}$. However, further studies are needed to understand the effects of understory plants on carbon dynamics in various ecosystems and thus to improve our estimates of ecosystem carbon sinks ${ }^{11}$.

Effects of stand age on ecosystem carbon storage. The NEP was reported to be negative in young plantations because, unlike mature plantations, carbon emission can exceed carbon storage in younger plantations ${ }^{15,46}$. Photosynthesis-derived carbon is usually low in the early stages of reforested plantations, which have a small leaf area index ${ }^{47}$, and it then increases over time. For instance, gross ecosystem photosynthesis across a boreal jack pine chronosequence was only

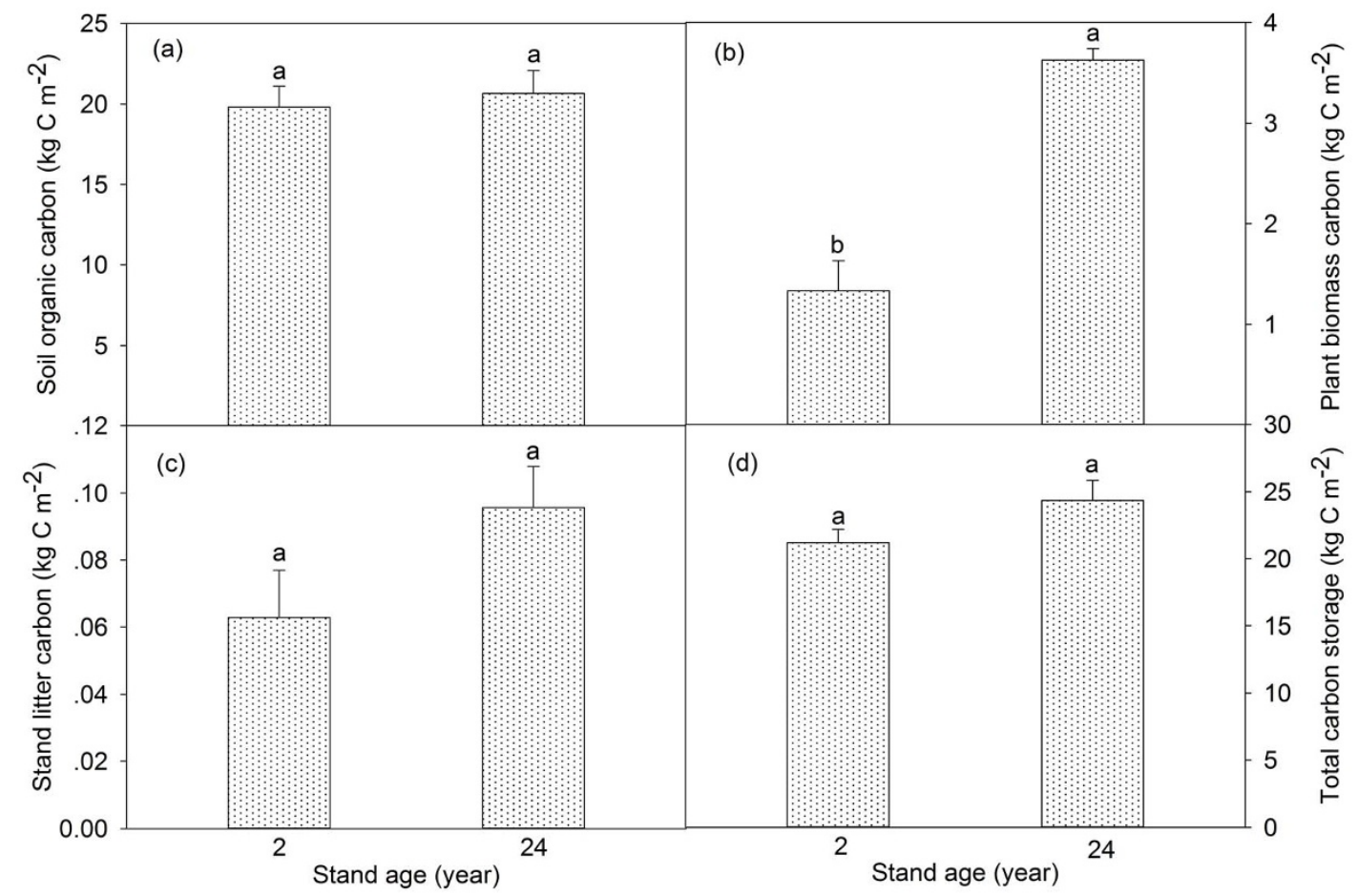

Figure 3 Soil organic carbon (a), plant biomass carbon (b), litter carbon (c), and total carbon (d) in the 2-year-old and 24-year-old plantations. Values shown are the mean $\pm 1 \mathrm{SE} ; \mathrm{n}=3$. Within each panel, means with different letters are significantly different $(P<0.05)$. 
Table 3 | Estimated forest area, net primary production (NPP, g C $\mathrm{m}^{-2} \mathrm{yr}^{-1}$ ) and net ecosystem production (NEP, $\mathrm{g} \mathrm{C} \mathrm{m}^{-2} \mathrm{yr}^{-1}$ ) of dominant forests in China. Forest area data were obtained from the seventh national forest resources inventory by the China Forestry Administration. ND, data not available. References for Table 3 are provided in the additional information

\begin{tabular}{lccc} 
Forest/plantation type & Area (M ha) & NPP & NEP \\
\hline Evergreen broad-leaved forest & $\mathrm{ND}$ & 1003.7 & 533.3 \\
Quercus forest & 16.1 & 541.5 & $\mathrm{ND}$ \\
Pinus plantation & 12.3 & 610.4 & 408.6 \\
Chinese fir plantation & 11.3 & 522.7 & 367.7 \\
Betula forest & 10.8 & 341 & $\mathrm{ND}$ \\
Larix forest & 10.6 & 212.97 & $\mathrm{ND}$ \\
Populus forest & 10.1 & $\mathrm{ND}$ & 720.3 \\
Abies forest & 3.11 & 576.2 & $\mathrm{ND}$ \\
Eucalyptus forest & 3.68 & 1547.6 & 1239.7 \\
Average in China & 195 & 599.8 & 108.8 \\
\hline
\end{tabular}

$96 \mathrm{~g} \mathrm{C} \mathrm{m}^{-2} \mathrm{yr}^{-1}$ in 2-year-old stands but was $347 \mathrm{~g} \mathrm{C} \mathrm{m}^{-2} \mathrm{yr}^{-1}$ in 10 year-old stands and $576 \mathrm{~g} \mathrm{C} \mathrm{m}^{-2} \mathrm{yr}^{-1}$ in 29-year-old stands ${ }^{46}$. In the present study, however, the NEP of the 2-year-old plantations was positive and larger than that of the 24-year-old plantations. The NEP was $1337 \mathrm{~g} \mathrm{C} \mathrm{m}^{-2} \mathrm{yr}^{-1}$ in the 2-year-old and $420 \mathrm{~g} \mathrm{C} \mathrm{m}^{-2} \mathrm{yr}^{-1}$ in the 24-year-old plantations. We suspect that the rapid growth of young Eucalyptus trees explains why even young Eucalyptus plantations can act as important carbon sinks. It is important to note that the NPP and NEP in this study would be underestimated because the NPP calculation does not include all fine root biomass and root litter/ exudates.

An additional reason for the NEP being larger in the young plantations than in the mature plantations in the current study was that heterotrophic respiration was lower in the young plantations. Low rates of heterotrophic respiration in young Eucalyptus plantations have been previously reported ${ }^{28}$. The total carbon storage was not significantly different between the two plantation ages based on our study period of 2 years, as soil organic carbon accounts for most of the total carbon storage and usually does not increase until 30 years after afforestation ${ }^{48}$. It is important to note that the Eucalyptus plantations demonstrated higher NPP and NEP in comparison with other dominant forest types in China; thus, they have the potential to sequester more atmospheric carbon dioxide.

Conclusions. This field study showed the carbon dynamics and effects of plant component removal in Eucalyptus plantations of contrasting ages. Our results indicate that understory plants strongly affect soil respiration and account for $33.9 \%$ and $14.1 \%$ of the total net primary production in young and mature plantations, respectively, which confirms the ecological importance of understory plants in subtropical plantations. Furthermore, both young and mature Eucalyptus plantations sequester carbon $\left(4.2-13.4 \mathrm{t} \mathrm{C} \mathrm{ha}^{-1}\right.$ $\mathrm{yr}^{-1}$ ), which can help mitigate the increases in atmospheric $\mathrm{CO}_{2}$ concentrations. Because the area of Eucalyptus plantations in China is more than 3.7 million ha, we propose that these Eucalyptus plantations may be important carbon sinks. In addition, as our experiment was only conducted for two years, a longer period of investigation is needed to more clearly demonstrate the carbon dynamics of Eucalyptus plantations.

\section{Methods}

Site description. The experimental site was located at the Heshan National Field Research Station of Forest Ecosystem (112 $50^{\prime}$ E, $22^{\circ} 34^{\prime}$ N; Guangdong Province, China), one of the core field stations for the Chinese Ecosystem Research Network (CERN). The climate in this region is subtropical monsoon. The mean annual precipitation is $1534 \mathrm{~mm}$, and the mean annual temperature from 2004 to 2009 was $22.5^{\circ} \mathrm{C}$. The soil in this area is classified as Ultisol according to USDA soil taxonomy. The prior vegetation type was Pinus forest. After logging, the vegetation residues were left on the stand and burned. Next, the Eucalyptus plantations were established. In these plantations, Eucalyptus saplings were planted with a spacing of $3 \mathrm{~m} \times 2 \mathrm{~m}$ and a density of approximately 1660 trees ha ${ }^{-1}$. Six experimental Eucalyptus plantations on homogenous degraded hilly areas were used. Three plantations were 24 years old (established in 1984), and the remaining plantations were 2 years old (established in 2006). Understory species in both plantations are dominated by Dicranopteris dichotoma; other understory species include Rhodomyrtus tomentosa, Baeckea frutescens, Dianella ensifolia, Wikstroemia indica, and Blechnum orientale ${ }^{22}$. Indigenous tree species are rare within the study site because of seed resource limitation and dense understory plants ${ }^{24}$. In March 2009, the mean understory biomass was $772 \pm 92 \mathrm{~g}$ dry weight $\mathrm{m}^{-2}$ in 2-year-old plantations and $2116 \pm 61 \mathrm{~g}$ dry weight $\mathrm{m}^{-2}$ in 24 -year-old plantations. The vegetation was considered to consist of two functional groups: overstory Eucalyptus trees and the Dicranopteris dichotoma-dominated understory.

Experimental design. One experimental plot $(10 \mathrm{~m} \times 10 \mathrm{~m})$ was established in each plantation from December 2007 to January 2008. Each plot was divided into four subplots; each of the four subplots corresponded to one treatment. The randomized block design had two levels for each of the two factors ( \pm girdling and \pm understory removal). There were four treatment combinations: no girdling and no understory removal (CK, or control); girdling but no understory removal $(\mathrm{G})$; no girdling but understory removal (UR), and girdling plus understory removal (GUR). A 40-cmdeep trench was created around each subplot to eliminate the intrusion of roots from the other subplots. Understory removal and tree girdling were performed in March 2008. Understory plants were manually removed with a machete. For girdling, we cut $10-\mathrm{cm}$ bands around the stem of each Eucalyptus tree in the designated plots at $50 \mathrm{~cm}$ above the soil surface. Because Eucalyptus can resprout after girdling and Dicranopteris can grow from remnant roots, the new growth of Eucalyptus and Dicranopteris (and growth of any other understory plant) was removed monthly ${ }^{22}$.

Soil $\mathrm{CO}_{2}$ efflux. Soil respiration was measured monthly from March 2008 to December 2008 and bimonthly from January 2009 to March 2010 between 9:00 a.m. and 12:00 a.m. with an LI-8100 automated soil $\mathrm{CO}_{2}$ flux system (LI-COR Inc., Lincoln, NE, USA). To measure soil respiration, three PVC collars $(20 \mathrm{~cm}$ diameter and $5 \mathrm{~cm}$ height) were placed at a depth of $2 \mathrm{~cm}$ in each subplot, and small living plants in the soil collars were removed by hand. PVC collars remained fixed throughout the experiment. Soil temperature at $5-\mathrm{cm}$ depth and volumetric soil moisture were measured by probes attached to the automated $\mathrm{CO}_{2}$ measurement device when the respiration was recorded. The soil respiration in plots with understory removal plus tree girdling was considered to be heterotrophic respiration $\left(R_{h}\right)$. Cumulative soil respiration for each treatment was determined by summing the amount of soil respiration with the number of days between sampling times ${ }^{25-27}$.

Net primary production and net ecosystem production. Biometric approaches were used to estimate net primary production (NPP, $\mathrm{g} \mathrm{C} \mathrm{m}^{-2} \mathrm{yr}^{-1}$ ) and net ecosystem production (NEP, $\mathrm{g} \mathrm{C} \mathrm{m}^{-2} \mathrm{yr}^{-1}$ ) (for details, see Chen et al. 2011). Briefly, seven typical trees were harvested to calculate total dry biomass. The allometric relationships between tree biomass and the diameter at breast height $(\mathrm{DBH}, 1.3 \mathrm{~m})$ and tree height were determined. The DBH and height of all trees within the plots were measured in April 2008 and April 2009. At the same time, to estimate understory plant biomass, we harvested the aboveground and belowground parts of all understory plants in two $1 \times 1 \mathrm{~m}$ subplots in each of the three replicated plots of each plantation. Understory plants were dried to constant mass at $75^{\circ} \mathrm{C}$. The value for carbon concentration was $0.457^{28}$.

Annual litter input was determined by deploying three nylon-mesh litter traps $(1 \mathrm{~m} \times 1 \mathrm{~m})$ at each plantation from July 2008 to July 2009 . Litter was collected monthly and dried to a constant mass at $75^{\circ} \mathrm{C}$. The biomass of fine roots (diameter $<$ $2 \mathrm{~mm}$ ) was determined by collecting five soil cores every 3 months $(8 \mathrm{~cm}$ diameter, $20 \mathrm{~cm}$ depth) in the subplots from March 2009 to March 2010 and a final time in November 2010 to investigate the effects of girdling and understory removal on fine root biomass. In the laboratory, fine roots were removed from the soil, rinsed with deionized water, and dried to constant mass. The sum of biomass increases in Eucalyptus trees, understory plants, roots, and litterfall was considered to be NPP. The cumulative soil respiration in plots with understory removal plus tree girdling was considered to be cumulative heterotrophic respiration $\left(R_{h}\right)$. The difference between NPP and $R_{h}$ was considered to be NEP.

The sum of soil organic carbon, floor litter carbon, and stand plant biomass was considered ecosystem carbon storage. For the determination of floor litter carbon storage, two $1 \mathrm{~m} \times 1 \mathrm{~m}$ subplots were selected in each plot of the plantations in 2008 . The floor litter was collected and dried to a constant mass at $75^{\circ} \mathrm{C}$. Data for soil organic carbon and soil bulk density were obtained from Wu et al. (2011b), who conducted research in the same plots.

Statistical analyses. We used one-way analysis of variance (ANOVA) to analyze the effects of treatments on soil respiration, soil temperature, soil moisture, ecosystem carbon storage, NPP, and NEP. Repeated measures analysis of variance (RM ANOVA) was used to determine the effects of sampling time, understory removal, and girdling on soil respiration, soil temperature, and soil moisture content. The between-subject effects were understory removal, girdling, and their interaction, and the within-subject effects were sampling time and its interaction with understory removal and girdling. The statistical analyses were conducted using SPSS 15 (SPSS, Inc., Chicago, IL, USA). Differences were considered significant at the 0.05 level. 
1. Dixon, R. et al. Carbon pools and flux of global forest ecosystems. Science 263, 185-189 (1994).

2. Luo, Y. et al. Elevated $\mathrm{CO}_{2}$ differentiates ecosystem carbon processes: deconvolution analysis of Duke Forest FACE data. Ecol. Monogr. 71, 357-376 (2001).

3. Heimann, M. \& Reichstein, M. Terrestrial ecosystem carbon dynamics and climate feedbacks. Nature 451, 289-292 (2008).

4. Schlesinger, W. \& Andrews, J. Soil respiration and the global carbon cycle. Biogeochemistry 48, 7-20 (2000).

5. Luo, Y. \& Zhou, X. Soil Respiration and the Environment. (Academic Press/ Elsevier, San Diego, CA, USA, 2006)

6. Raich, J. \& Schlesinger, W. The global carbon dioxide flux in soil respiration and its relationship to vegetation and climate. Tellus 44, 81-99 (1992).

7. Rustad, L. et al. A meta-analysis of the response of soil respiration, net nitrogen mineralization, and aboveground plant growth to experimental ecosystem warming. Oecologia 126, 543-562 (2001).

8. Raich, J., Potter, C. \& Bhagawati, D. Interannual variability in global soil respiration: 1980-94. Glob. Change Biol. 8, 800-812 (2002).

9. Pan, Y. et al. A large and persistent carbon sink in the world's forests. Science 333, 988-993 (2011).

10. China Forestry Administration. The seventh national forest resources inventory and the status of forest resources. For. Resour. Manage. 1, 1-8 (2010).

11. Piao, S. et al. The carbon balance of terrestrial ecosystems in China. Nature 458, 1009-1013 (2009).

12. Feng, X., Fu, B., Lu, N., Zeng, Y. \& Wu, B. How ecological restoration alters ecosystem services: an analysis of carbon sequestration in China's Loess Plateau. Sci. Rep. 3, 2846; DOI:10.1038/serp02846 (2013).

13. Chapin, F. S. I. et al. Reconciling carbon-cycle concepts terminology, and methods. Ecosystems 9, 1041-1050 (2006).

14. Lovett, G. M., Cole, J. J. \& Pace, M. L. Is net ecosystem production equal to ecosystem carbon accumulation? Ecosystems 9, 1-4 (2006).

15. Pregitzer, K. S. \& Euskirchen, E. S. Carbon cycling and storage in world forests: biome patterns related to forest age. Glob. Change Biol. 10, 2052-2077 (2004)

16. Wan, S., Xia, J., Liu, W. \& Niu, S. Photosynthetic overcompensation under nocturnal warming enhances grassland carbon sequestration. Ecology $\mathbf{9 0}$, 2700-2710 (2009).

17. Bartels, S. \& Chen, H. Is understory plant species diversity driven by resource quantity or resource heterogeneity? Ecology 91, 1931-1938 (2010).

18. Nilsson, M.-C. \& Wardle, D. A. Understory vegetation as a forest ecosystem driver: evidence from the northern Swedish boreal forest. Front. Ecol. Environ. 3, 421-428 (2005).

19. Wu, J. et al. Understory plants can make substantial contributions to soi respiration: Evidence from two subtropical plantations. Soil Biol. Biochem. 43, 2355-2357 (2011).

20. Norby, R. et al. Forest response to elevated $\mathrm{CO}_{2}$ is conserved across a broad range of productivity. Proc. Natl. Acad. Sci. USA. 102, 18052-18056 (2005).

21. Yang, M., Xie, Y. \& Liu, J. Eucalyptus Research in China (1981-2010). (China Forestry Press, Beijing, China, 2011).

22. Wu, J. et al. Effects of understory removal and tree girdling on soil microbia community composition and litter decomposition in two Eucalyptus plantations in South China. Funct. Ecol. 25, 921-931 (2011).

23. Camprodon, J. \& Brotons, L. Effects of undergrowth clearing on the bird communities of the Northwestern Mediterranean Coppice Holm oak forests. For. Ecol. Manage. 221, 72-82 (2006).

24. Wang, J., Ren, H., Yang, L. \& Duan, W. Establishment and early growth of introduced indigenous tree species in typical plantations and shrubland in South China. For. Ecol. Manage. 258, 1293-1300 (2009)

25. Xu, M. \& Qi, Y. Soil-surface $\mathrm{CO}_{2}$ efflux and its spatial and temporal variations in a young ponderosa pine plantation in northern California. Glob. Change Biol. 7, 667-677 (2001).

26. Tang, X., Liu, S., Zhou, G., Zhang, D. \& Zhou, C. Soil-atmospheric exchange of $\mathrm{CO}_{2}, \mathrm{CH}_{4}$, and $\mathrm{N}_{2} \mathrm{O}$ in three subtropical forest ecosystems in southern China. Glob. Change Biol. 12, 546-560 (2006).

27. Bremer, D., Ham, J., Owensby, C. \& Knapp, A. Responses of soil respiration to clipping and grazing in a tallgrass prairie. J. Environ. Qual. 27, 1539-1548 (1998).

28. Chen, D. et al. Subtropical plantations are large carbon sinks: Evidence from two monoculture plantations in South China. Agr. Forest Meteorol. 151, 1214-1225 (2011)

29. Binkley, D., Stape, J. L., Takahashi, E. N. \& Ryan, M. G. Tree-girdling to separate root and heterotrophic respiration in two Eucalyptus stands in Brazil. Oecologia 148, 447-454 (2006).

30. Chen, D., Zhang, Y., Lin, Y., Zhu, W. \& Fu, S. Changes in belowground carbon in Acacia crassicarpa and Eucalyptus urophylla plantations after tree girdling. Plant Soil 326, 123-135 (2010).
31. Högberg, P. et al. Large-scale forest girdling shows that current photosynthesis drives soil respiration. Nature 411, 789-792 (2001).

32. Bhupinderpal-Singh et al. Tree root and soil heterotrophic respiration as revealed by girdling of boreal Scots pine forest: extending observations beyond the first year. Plant Cell Environ. 26, 1287-1296 (2003).

33. Fu, S. L. \& Cheng, W. X. Rhizosphere priming effects on the decomposition of soil organic matter in C-4 and C-3 grassland soils. Plant Soil 238, 289-294 (2002).

34. Wang, X. et al. Impacts of understory species removal and/or addition on soil respiration in a mixed forest plantation with native species in southern China. For. Ecol. Manage. 261, 1053-1060 (2011)

35. Li, Y., Xu, M. \& Zou, X. Effects of nutrient additions on ecosystem carbon cycle in a Puerto Rican tropical wet forest. Glob. Change Biol. 12, 284-293 (2006).

36. Curiel Yuste, J., Nagy, M., Janssens, I., Carrara, A. \& Ceulemans, R. Soil respiration in a mixed temperate forest and its contribution to total ecosystem respiration. Tree Physiol. 25, 609-619 (2005).

37. Farley, K., Jobbágy, E. \& Jackson, R. Effects of afforestation on water yield: a global synthesis with implications for policy. Glob. Change Biol. 11, 1565-1576 (2005).

38. Chen, R., Corlett, R. \& Hill, R. Effects of harvesting on the biomass of plant species. For. Ecol. Manage. 103, 69-76 (1998).

39. Reich, P. B., Frelich, L. E., Voldseth, R. A., Bakken, P. \& Adair, C. Understorey diversity in southern boreal forests is regulated by productivity and its indirect impacts on resource availability and heterogeneity. J. Ecol. 100, 539-545 (2012).

40. Gower, S. et al. Net primary production and carbon allocation patterns of boreal forest ecosystems. Ecol. Appl. 11, 1395-1411 (2001).

41. Clark, D. et al. Measuring net primary production in forests: concepts and field methods. Ecol. Appl. 11, 356-370 (2001).

42. Brown, S. Estimating Biomass and Biomass Change of Tropical Forests: a Primer. (Food and Agriculture Organization, Rome, Italy, 1997).

43. Zhang, J. et al. Carbon storage by ecological service forests in Zhejiang Province, subtropical China. For. Ecol. Manage. 245, 64-75 (2007).

44. Zhou, C. et al. Impacts of a large-scale reforestation program on carbon storage dynamics in Guangdong, China. For. Ecol. Manage. 225, 847-854 (2008).

45. Yu, Z. \& Peng, S. The artificial and natural restoration of tropical and subtropical forests. Acta Ecol. Sinica 15, 1-16 (1995).

46. Zha, T. et al. Carbon sequestration in boreal jack pine stands following harvesting. Glob. Change Biol. 15, 1475-1487 (2009).

47. Humphreys, E. R., Black, T. A., Morgenstern, K., LI, Z. \& Nesic, Z. Net ecosystem production of a Douglas-fir stand for 3 years following clearcut harvesting. Glob. Change Biol. 11, 450-464 (2005).

48. Li, D., Niu, S. \&Luo, Y. Global patterns of the dynamics of soil carbon and nitrogen stocks following afforestation: a meta-analysis. New Phytol. 195, 172-181 (2012).

\section{Acknowledgments}

This work was funded by the National Science Foundation of China (NO. 31210103920 31160153), the National Basic Research Program of China (NO. 2011CB403204), and Funding by the Nanchang Institute of Technology and Jiangxi Provincial Department of Education (KJLD12097, GJJ14744).

\section{Author contributions}

J.P.W., Z.F.L. and S.L.F. conceived and designed the experiments. J.P.W., G.M.H., D.M.C. and S.Z.W. performed the experiments. J.P.W., W.X.Z., D.M.C. and Y.H.S. analyzed the data. J.P.W., S.L.F. and Z.F.L. wrote the manuscript.

\section{Additional information}

Supplementary information accompanies this paper at http://www.nature.com/ scientificreports

Competing financial interests: The authors declare no competing financial interests How to cite this article: $\mathrm{Wu}$, J. et al. Response of soil respiration and ecosystem carbon budget to vegetation removal in Eucalyptus plantations with contrasting ages. Sci. Rep. 4, 6262; DOI:10.1038/srep06262 (2014)

This work is licensed under a Creative Commons Attribution-NonCommercialShareAlike 4.0 International License. The images or other third party material in this article are included in the article's Creative Commons license, unless indicated otherwise in the credit line; if the material is not included under the Creative Commons license, users will need to obtain permission from the license holder in order to reproduce the material. To view a copy of this license, visit http:// creativecommons.org/licenses/by-nc-sa/4.0/ 